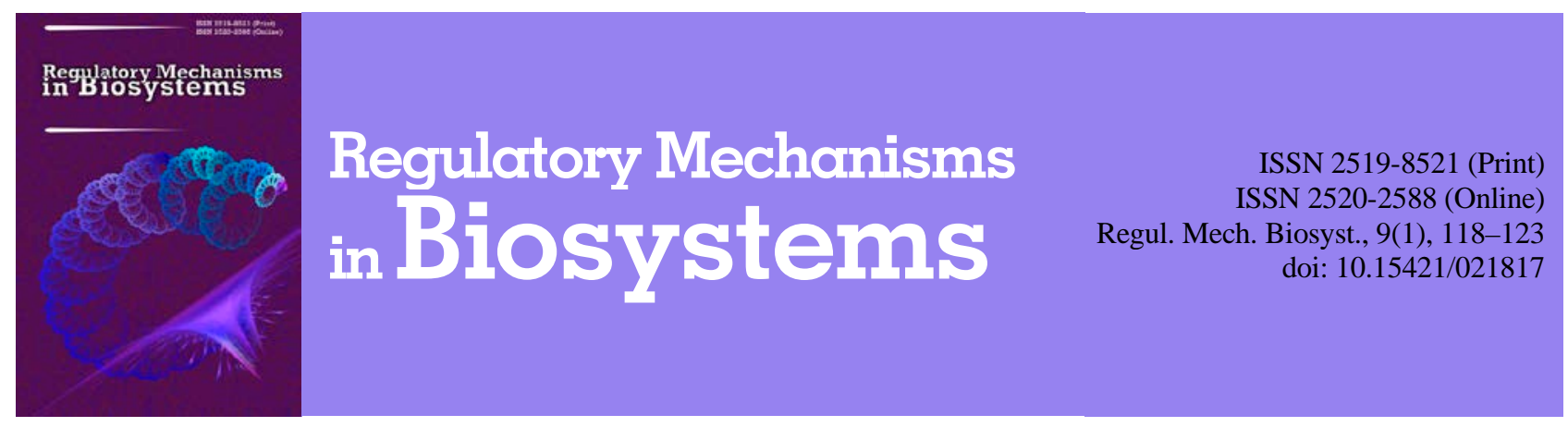

\title{
The impact of certain flavourings and preservatives on the survivability of larvae of nematodes of Ruminantia
}

\author{
O. O. Boyko*, V. V. Brygadyrenko** \\ *Dnipro State Agrarian-Economic University, Dnipro, Ukraine \\ **Oles Honchar Dnipro National University, Dnipro, Ukraine
}

Article info

Received 03.01.2018

Received in revised form 29.01.2018

Accepted 31.01.2018

Dnipro State Agrarian and Economic University, Serhii Efremov st., 25, Dnipro, 49600, Ukraine

Oles Honchar Dnipro National University, Gagarin Ave., 72, Dnipro, 49010, Ukraine. Tel. +38-050-939-07-88. E-mail:brigad@ua.fm

\begin{abstract}
Boyko, O. O., \& Brygadyrenko, V. V. (2018). The impact of certain flavourings and preservatives on the survivability of larvae of nematodes of Ruminantia. Regulatory Mechanisms in Biosystems, 9(1), 118-123. doi: 10.15421/021817

Annualy, helminthic diseases are one of the causes of economic losses in agriculture. Ruminantia are most often observed to be infected with nematodes of the gastrointestinal tract, including Strongyloides papillosus and the representatives of the Strongylida order. Identifying factors which could cause a decrease in the level of infection of agricultural animals with helminthiases would allow stock-raising facilities to regularly achieve high quality dairy and meat production in sufficient quantity. On the basis of this study, we determined the impact of flavourings and source materials approved for use in and on foods (isoamyl alcohol, isoamyl acetate, raspberry ketone, trilon B, methylparaben) on the survivability of larvae of Strongyloides papillosus and Haemonchus contortus, parasitic nematodes of Ruminantia animals. Among these substances, the lowest efficiency against the nematode larvae was found in isoamyl alcohol, isoamyl acetate and trilon B. A stronger effect was caused by methylparaben (for $\mathrm{L}_{3}$ S. papillosus $\mathrm{LD}_{50}=0.67 \pm$ $0.04 \%, \mathrm{~L}_{1}$ and $\mathrm{L}_{2}$ S. papillosus $-\mathrm{LD}_{50}=0.0038 \pm 0.0008 \%, \mathrm{~L}_{3} H$. contortus $\left.-\mathrm{LD}_{50}=0.89 \pm 0.15 \%\right)$. Minimum efficient dosage of the solutions was $10 \mathrm{~g} /$ l. Significant antihelminthic properties were manifested by raspberry ketone (for $\mathrm{L}_{3}$ S. papillosus $\mathrm{LD}_{50}=1.00 \pm 0.72 \%, \mathrm{~L}_{1}$ and $\mathrm{L}_{2}$ S. papillosus $-\mathrm{LD}_{50}=0.07 \pm 0.06 \%, \mathrm{~L}_{3} H$. contortus $-\mathrm{LD}_{50}=$ $0.39 \pm 0.26 \%$ ). The results show that there is considerable potential for further studies on the antiparasitic properties of these substances against nematodes in the conditions of farming enterprises and agricultural complexes.
\end{abstract}

Keywords: Strongyloides papillosus; Haemonchus contortus; antiparasitic activity; flavouring agents; isoamyl alcohol; isoamyl acetate; raspberry ketone; Trilon B; methylparaben

\section{Introduction}

Throughout the world a daily struggle takes place against parasitic diseases of agricultural animals. These infestations cause significant economic damage to farming enterprises and large stock-raising facilities, which consequently fall short of their potential in meat and dairy production. The most common parasitic diseases are helminthiases (Vercruysse et al., 2001; Biffa et al., 2007; Van der Voorta et al., 2013; Boyko et al., 2016). Ruminantia in Ukraine and other countries of Europe are regularly observed to be infected with the following nematodes of gastrointestinal tract: Haemonchosis, Nematodirus, Trichostrongyloidosis, Chabertiosis, Bunostomosis, Protostrongylidoses, Strongyloides, etc. (Lindqvist et al., 2001; Bhutto et al., 2002). Some of the abovementioned parasites are related to the feeding of nematodes on the blood of mammal hosts. As a result, the biochemical indicators of the milk of cattle, sheep and goats change (Boyko et al., 2016). The quality of the meat products decreases as well. The helminths constantly release a significant number of toxins into the host's organism, causing intoxication (Faye et al., 2003; Cringoli et al., 2008).

In the struggle against helminthic diseases, therapeutic and preventive measures play a significant role. They are aimed at chemotherapy and chemoprophylaxis with the use of anthelminthic preparations. The most common (Ploeger et al., 1990; Kloosterman et al., 1996; Veneziano et al., 2004) preparations against helminths are broad-spectrum preparations on the basis of macrocyclic lactones (Ivermectin, Doramectin, Abamectin, etc), Benzimidazoles
(Albendazole, Mebendazole, Fenbendazole). Modern veterinary medicine also applies alternative methods against helminths using herbaceous preparations. However, the extent of their impact is differently interpreted by various authors (Rahmann \& Seip, 2006; Burke et al., 2009; Cheng et al., 2009; Lu et al., 2010; Chhetri et al., 2015; González-Coloma et al., 2017). For preventing helminthic infestations, it is recommended to cultivate the pastures, plough the land on their territories, provide a pen-system of grazing, conduct mechanical cleaning from bushes, rocks, drying, and taking measures against intermediate hosts and other methods. Our previous studies devoted to the impact of food additives on the survivability of the larvae of the nematode of pigs Strongyloides ransomi (Schwartz and Alicata, 1930), and eggs of Ascaris suuum Goeze, 1782 indicated positive results for certain flavourings, preservatives and other types of food additives used in the food industry. Therefore, a relevant issue today is determining their impact on other species of nematodes often found in agricultural animals (Boyko et al., 2017).

\section{Materials and methods}

In the summer of 2017, we collected faeces of Ruminantia on the territory of Dnipropetrovsk oblast of Ukraine to the amount of $100 \mathrm{~g}$ from every individual $(\mathrm{n}=56)$. The material was transported in plastic containers at a temperature of $22-24{ }^{\circ} \mathrm{C}$ to the parasitelogical laboratory of Dnipro State Agrarian-Economic University. The samples with helminths for use in the experiment were 
identified using the McMaster method. For the study, we selected third age larvae $\left(\mathrm{L}_{3}\right)$ of Haemonchus contortus (Rudolphi, 1803) from the Strongylida order and larvae of first, second and third age $\left(\mathrm{L}_{1}, \mathrm{~L}_{2}, \mathrm{~L}_{3}\right)$ of Strongyloides papillosus (Wedl, 1856) from the
Rhabditida order (Van Wyk \& Mayhew, 2013) (Fig. 1). For the experiment, the larvae were cultivated during 8 days at a temperature of $22-24{ }^{\circ} \mathrm{C}$. The larvae material was collected using the Baermann test (Zajac \& Conboy, 2011).

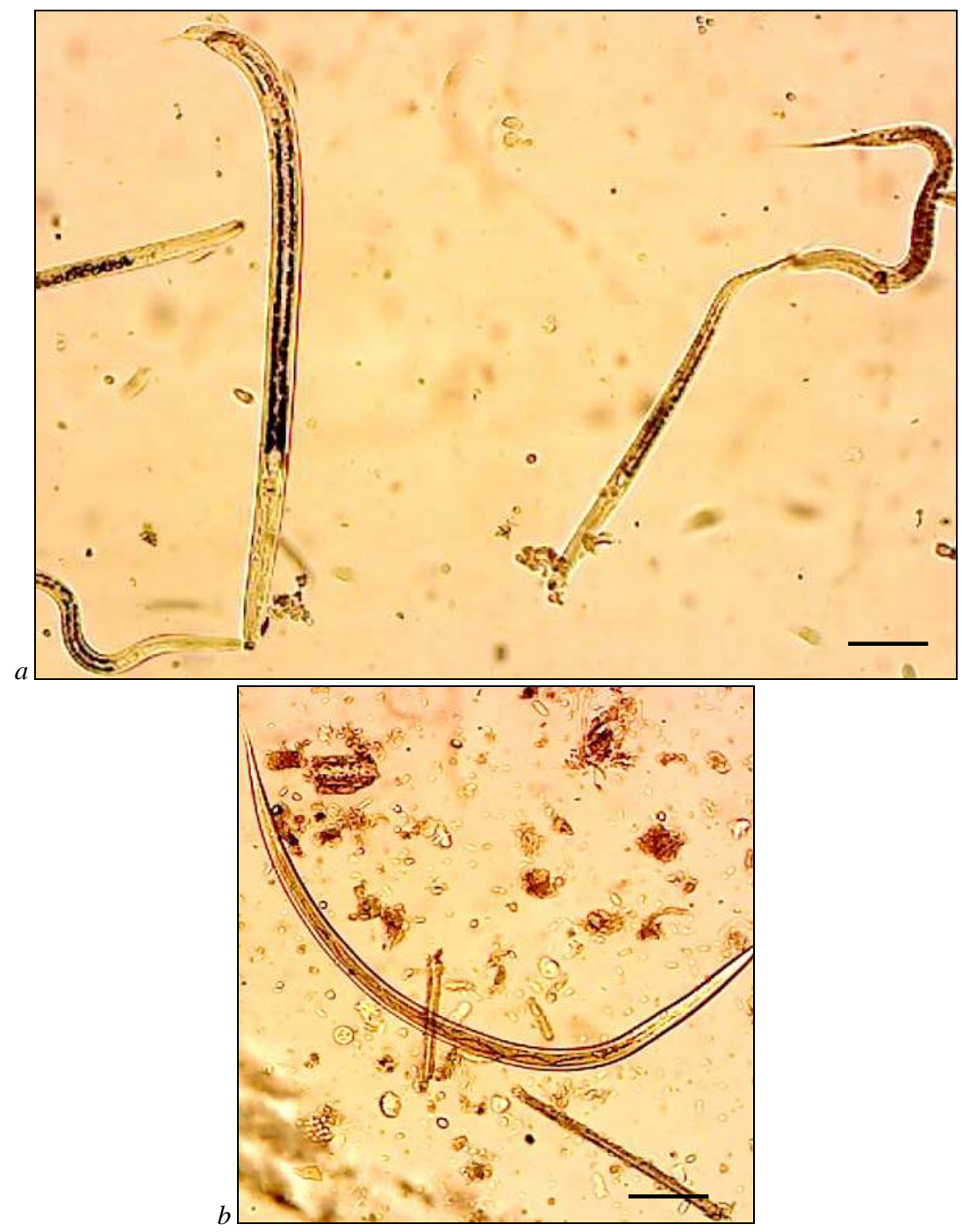

Fig. 1. Strongyloides papillosus (Wedl, 1856) of different ages (a) and Haemonchus contortus (Rudolphi, 1803) $\mathrm{L}_{3}(b)$ : bar - $10 \mu \mathrm{m}$

\section{Table 1}

Usage and properties of the flavourings and preservatives* used for determining the level of survivability of Strongyloides papillosus (Wedl, 1856) and Haemonchus contortus (Rudolphi, 1803) larvae

\begin{tabular}{|c|c|c|c|c|c|c|}
\hline \multirow{2}{*}{ Substance name } & \multirow{2}{*}{$\begin{array}{l}\text { Chemical } \\
\text { formula }\end{array}$} & \multirow{2}{*}{ Structural formula } & \multirow{2}{*}{ Properties } & \multirow{2}{*}{ Content } & \multicolumn{2}{|c|}{ Usage } \\
\hline & & & & & in food industry & in medicine \\
\hline $\begin{array}{l}\text { Isoamyl alcohol } \\
\text { (3-methylbu-tan-1-ol) }\end{array}$ & $\mathrm{C}_{5} \mathrm{H}_{12} \mathrm{O}$ & & $\begin{array}{c}\text { optically inactive } \\
\text { colourless substance } \\
\text { with unpleasant odour }\end{array}$ & fusel oils & $\begin{array}{l}\text { used for preparing } \\
\text { extractions with pleasant } \\
\text { fruit odour }\end{array}$ & no data on usage \\
\hline $\begin{array}{c}\text { Isoamyl acetate } \\
\text { (3-methyl-butyl acetate) }\end{array}$ & $\mathrm{C}_{7} \mathrm{H}_{14} \mathrm{O}_{2}$ & & $\begin{array}{l}\text { colourless substance } \\
\text { with sharp pear odour }\end{array}$ & in some fruits & $\begin{array}{l}\text { pear extraction for produ- } \\
\text { cing fruit water, caramel, } \\
\text { etc. }\end{array}$ & no data on usage \\
\hline $\begin{array}{l}\text { Raspberry ketone } \\
\text { (4-(4-hydroxyphenyl) } \\
\text { butan-2-one) }\end{array}$ & $\mathrm{C}_{10} \mathrm{H}_{12} \mathrm{O}_{2}$ & & $\begin{array}{l}\text { colourless substance } \\
\text { with citrus odour }\end{array}$ & $\begin{array}{l}\text { in red } \\
\text { raspberries }\end{array}$ & $\begin{array}{l}\text { as a food additive with fruit } \\
\text { flavour }\end{array}$ & used in cosmetology \\
\hline $\begin{array}{c}\text { Trilon B } \\
\text { (2,2',2",2"'-(ethane-1,2- } \\
\text { diyldinitrilo)tetra-acetic } \\
\text { acid), } \mathrm{E}_{385}\end{array}$ & $\mathrm{C}_{10} \mathrm{H}_{16} \mathrm{~N}_{2} \mathrm{Na}_{2} \mathrm{O}_{8}$ & & $\begin{array}{l}\text { white crystalline } \\
\text { powder or crystals of } \\
\text { white colour }\end{array}$ & - & $\begin{array}{l}\text { in food preservation, as } \\
\text { antioxidant }\end{array}$ & $\begin{array}{l}\text { in the production of medical } \\
\text { preparations and in cases of } \\
\text { heavy metal intoxication, in } \\
\text { dentistry, as a preservative in } \\
\text { eye preparations }\end{array}$ \\
\hline Methylparaben, $\mathrm{E}_{218}$ & $\mathrm{C}_{8} \mathrm{H}_{8} \mathrm{O}_{3}$ & & $\begin{array}{l}\text { white crystalline } \\
\text { substance with } \\
\text { distinctive odour }\end{array}$ & $\begin{array}{l}\text { in the roots of } \\
\text { Oxalis } \\
\text { tuberose }\end{array}$ & as a preservative & as an antiseptic \\
\hline
\end{tabular}

Note: * - properties of the substances are given according to Lide, 1980; Fahlbusch et al., 2002; Soni et al., 2002; Catalog of Organics and Fine Chemicals, 2004; Nomenclature of Organic Chemistry, 2014. 
Sediment with larvae was obtained by centrifugation (4 minutes at 1500 circles per minute), which was put into $1.5 \mathrm{ml}$ plastic test tubes in equal portions. Then $1 \mathrm{ml}$ of $1.0 \%$ water solution of each tested substance was added to the larvae cultures $(0.1 \mathrm{ml}, 20$ 40 ind.). The exposure lasted 24 hours. The temperature regime in the thermostat was within $22-24{ }^{\circ} \mathrm{C}$. The nematode larvae were affected by food additives from the group of flavourings, and also preservatives (the experiment used three concentrations of the tested substances: $1 \%, 0.01 \%, 0.0001 \%$ ). Every variant of the experiment was repeated eight times. The laboratory studies were conducted using chemically pure isoamyl alcohol, isoamyl acetate, raspberry ketone, Trilon B, and methylparaben (Table 1).

The statistical analysis of the results was performed through a set of Statistica 8.0 (StatSoft Inc., USA), the figures is show the median, $25 \%$ and $75 \%$ quartiles, minimum and maximum values. $\mathrm{LD}_{50}(\%)$ was calculated as average $(\mathrm{x}) \pm$ standard deviation (SD).

\section{Results}

The results indicated a complete absence of anthelminthic properties in isoamyl alcohol (Fig. 2a) and isoamyl acetate. With expo- sure to isoamyl alcohol, we observed around $60 \%$ vital larvae of $\mathrm{L}_{3}$ S. papillosus in $1 \%$ solution. Less resistant to the impact of isoamyl alcohol were $L_{1}$ and $L_{2} S$. papillosus. The percentage of the surviving larvae of these two stages after 24 hours of exposure to $1 \%$ solution was $55 \%$. With further solutions of isoamyl alcohol, $80 \%$ of $S$. papillosus larvae survived. Larvae of $\mathrm{L}_{3} \mathrm{H}$. contortus were found to be the most resistant to different concentrations of this substance. At $0.0001-1 \%$ solution of this alcohol, $100 \%$ of them survived.

The next flavouring, isoamyl acetate, manifested the weakest influence on the mortality of nematode larvae of Ruminantia (Fig. $2 b$ ). In $1 \%$ solution, almost all larvae of S. papillosus and $H$. contortus survived. Similarly, at $0.01 \%$ and $0.0001 \%$ concentrations of this substance, most of the larvae of all studied nematode species survived.

$1 \%$ solution of raspberry ketone caused $100 \%$ mortality only to $\mathrm{L}_{1}$ and $\mathrm{L}_{2} \mathrm{~S}$. papillosus. $30-50 \%$ of $\mathrm{L}_{3} \mathrm{~S}$. papillosus and $H$. contortus survived in this concentration. In $0.01 \%$ solution of this substance, over $80 \%$ of the Ruminantia nematode larvae survived. $0.0001 \%$ concentration of raspberry ketone in $100 \%$ of cases did not affect the survivability of these parasites (Fig. 2c).

$$
\mathrm{L}_{3} \text { S. papillosus } \quad \mathrm{L}_{1}, \mathrm{~L}_{2} \text { S. papillosus } \quad \mathrm{L}_{3} H \text {. contortus }
$$
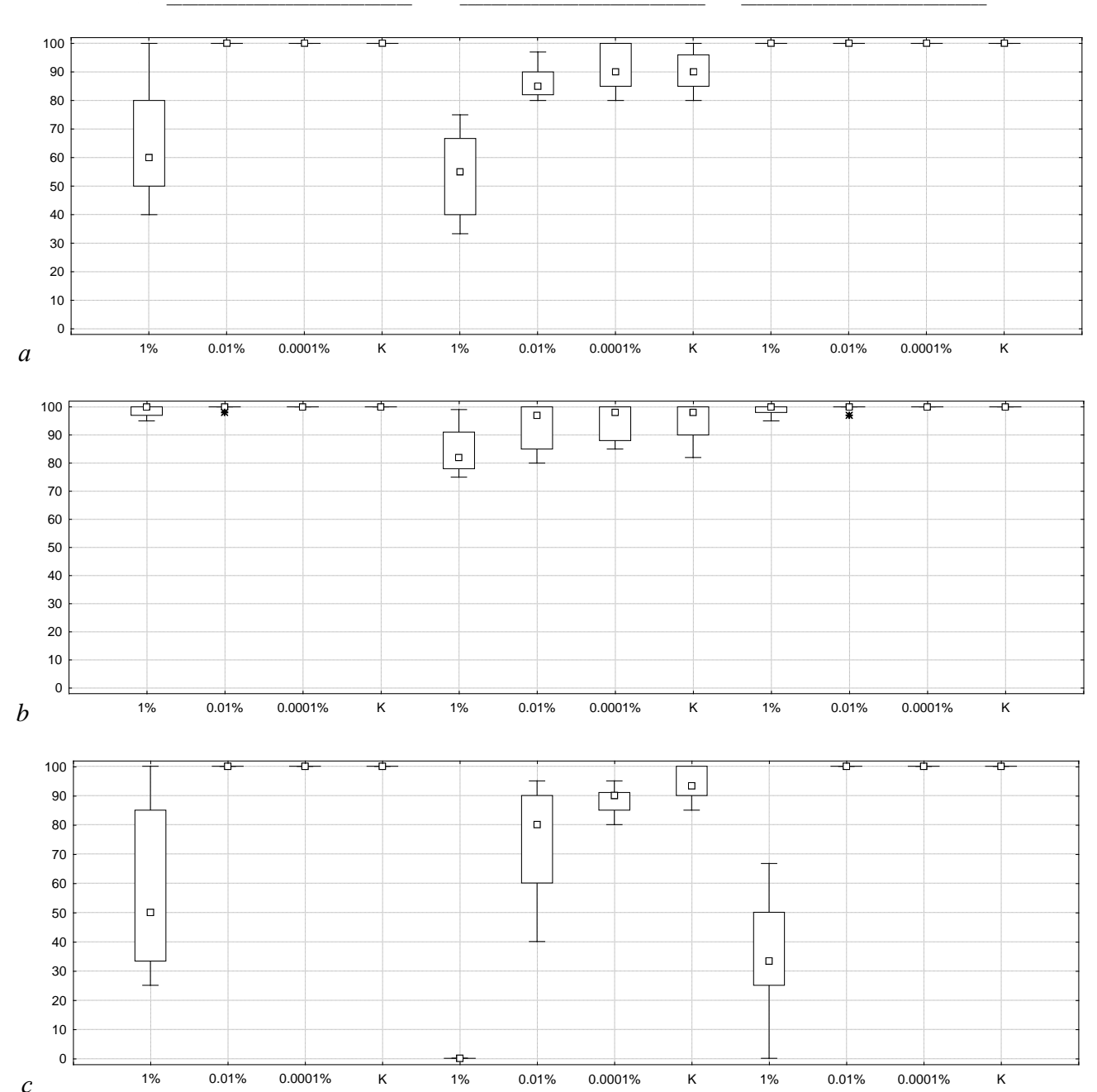

Fig. 2. The effect of flavourings on the survivability of Ruminantia nematodes: $a$-isoamyl alcohol, $b$-isoamyl acetate, $c$-raspberry ketone; the ordinate axis shows the percentage of nematode larvae which survived over the 24-hour experiment; the abscissa axis shows the concentration of the active substance in the solution (\%), $\mathrm{K}$ - control, where the concentration of the active substance equals $0 \%$; $\mathrm{L}_{3}$ - invasive larvae of $S$. papillosus or $H$. contortus, $\mathrm{L}_{1}, \mathrm{~L}_{2}$ - non-invasive larvae of $S$. papillosus; the small square in the center corresponds to the median, the lower and upper borders of the large rectangular correspond to the first and the third quartiles, respectively, vertical line segments, directed up and down from the rectangular, correspond to minimum and maximum values $(\mathrm{n}=8)$

The second stage of the experiment was determining the anthelminthic properties of some preservatives (trilon B and methylparaben). About $60 \%$ of $\mathrm{L}_{1}$ and $\mathrm{L}_{2}$ S. papillosus larvae died after
24 hours in $1 \%$ solution of trilon B. At the same concentration, all the rest of larvae survived in the percentage of $75-100 \%$. The most resistant to $1 \%$ solution of trilon B were the larvae of $H$. contortus 
(100\% larvae survived). The next solutions of trilon B had no positive effects - all larvae survived (Fig. 3a). The solution of methylparaben in $1 \%$ and $0.01 \%$ concentrations caused death of noninvasive S. papillosus (Fig. $3 b$ ) larvae in $100 \%$ of cases. Invasive larvae of this species, similarly to $H$. contortus larvae are sensitive to methylparaben only at its maximum, $1 \%$ concentration of the active substance. The analysis of the study results indicated complete absence of anthelminthic properties in isoamyl alcohol and trilon B. Minimum $\mathrm{LD}_{50}(\%)$ indicators for $\mathrm{L}_{3}$ S. papillosus were registered for isoamyl acetate, raspberry ketone и methylparaben (Table 2).
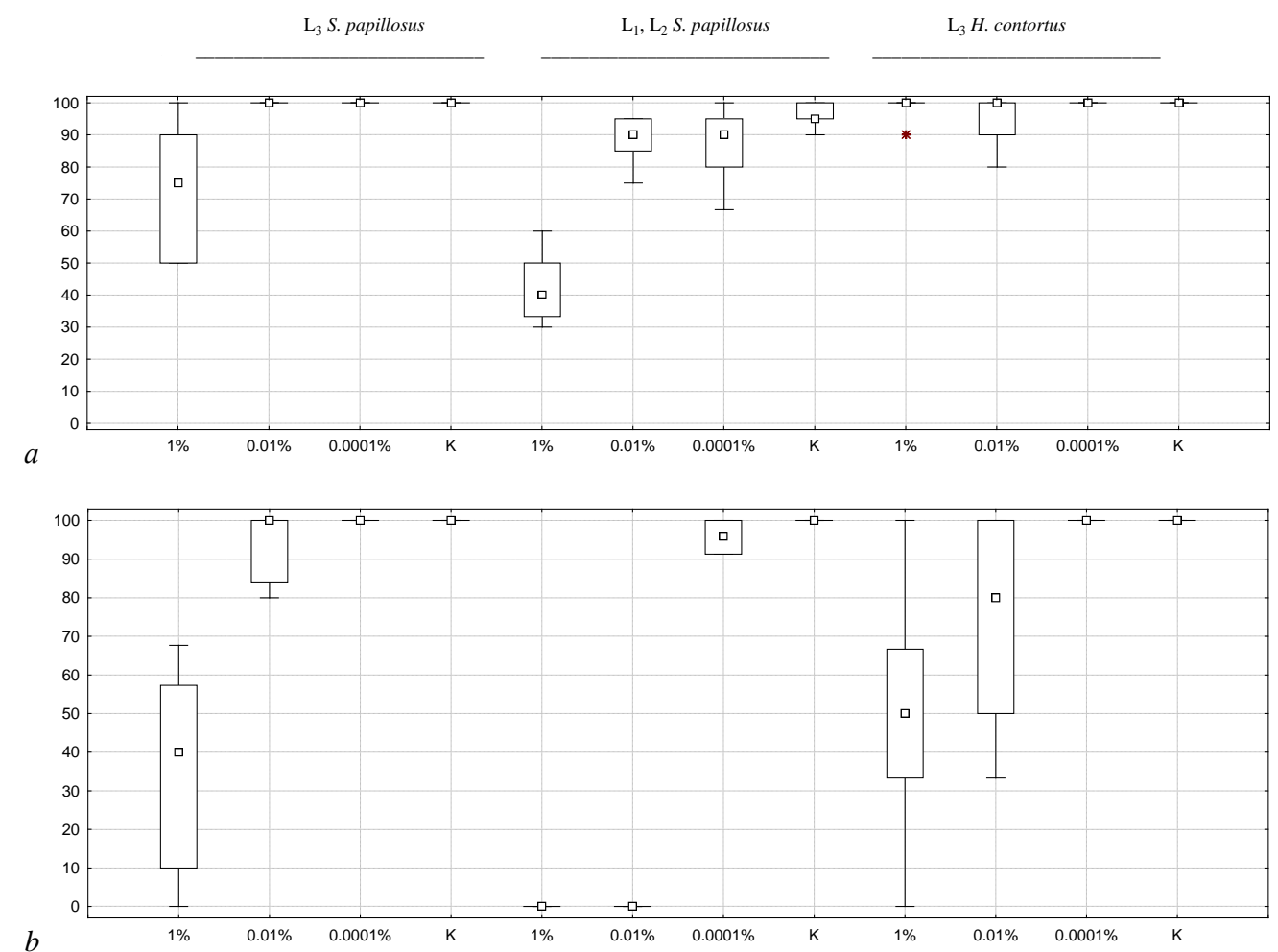

Fig. 3. The effect of trilon B (a) and methylparaben $(b)$ on the survivability of Ruminantia nematode larvae: see notes to Fig. 1

\section{Table 2}

$\mathrm{LD}_{50}(\%, \mathrm{x} \pm \mathrm{SD})$ for $S$. papillosus and $H$. contortus larvae in laboratory experiment during 24 hours

\begin{tabular}{lccc}
\hline \multicolumn{1}{c}{ Substance } & S. papillosus, $\mathrm{L}_{3}$ & S. papillosus, $\mathrm{L}_{1}+\mathrm{L}_{2}$ & H. contortus, $\mathrm{L}_{3}$ \\
\hline isoamyl alcohol & - & - & - \\
isoamyl acetate & - & - & - \\
raspberry ketone & $1.00 \pm 0.72$ & $0.07 \pm 0.06$ & $0.39 \pm 0.26$ \\
trilon B & - & $0.80 \pm 0.46$ & - \\
methylparaben & $0.67 \pm 0.04$ & $0.0038 \pm 0.0008$ & $0.89 \pm 0.15$ \\
\hline
\end{tabular}

\section{Discussion}

Therefore, according to the results of our studies and analysis of the data from the literature, the additives used in the food industry can affect parasites, including nematode larvae of Ruminantia, in a certain concentration. Data on using food additives with the purpose of affecting the parasites are quite limited. Their impact on parasitic Acari and insects has been studied by Lee et al. (2008), Knoblauch and Fry (2011), Shen et al. (2012), Belkind et al. (2013) et al. Shen et al. (2012) indicate the significant effect of cinnamaldehyde against parasitic Acari Psoroptes. $\mathrm{LD}_{50}$ equals $107 \mathrm{mg} / \mathrm{ml}$, (with 24 hours exposure) for Acari of this genus. Also, this food additive has been studied by Na et al. (2011) as an acaricide preparation against Dermanyssus of birds. $\mathrm{LD}_{50}$ for Dermanyssus sp. was $0.54 \mathrm{mg} / \mathrm{ml}$ (with 24-hour exposure). According to Lee (2004), p-anisaldehyde food additive is capable of acaricide properties. Other works are devoted to the impact of the food additive cinnamaldehyde on larvae of blood-sucking insects. $\mathrm{LD}_{50}$ for larvae of mosquitoes was $40.8 \mathrm{mg} / \mathrm{ml}$. Taylor (2009) used benzyl alcohol against fleas and also indicated that this additive has insecticidal properties. Benzaldehyde has been proved to have an impact on insects. It was used against Galleria mellonella (Linnaeus, 1758). The authors of these studies, Ullah et al. (2015), recommended the additive for the compound of insecticidal preparations. Lee et al. (2008) have also used benzaldehyde $\left(\mathrm{LD}_{50}\right.$ with 48-hour exposure 0.004-0.200 mg/sm against Sitophilus oryzae (Linnaeus, 1763) (Coleoptera, Curculionidae). Anthelminth properties of benzyl alcohol additive were proved by Chalquest (2002). Pedersen and Woldum (2011) recommend using it as solvent of preparations against parasites.

Food additives are often used as antimicrobial agents. Their impact on microorganisms has been studied by Chiang et al. (2005), Sato et al. (2006), Somolinos et al. (2008), Si et al. (2009), Belletti et al. (2010) and many other authors. Ribeiro et al. (2016) have studied antimicrobial, antifungi, and also insecticidal impact of 83 compounds from different tissues of Ricinus communis. Some of them are used as additives in the food industry. They include alkaloids, terpenoids, flavonoids, benzoic acid derivatives, coumarins, tocopherols, and fatty acids. The antimicrobial properties of cinnamaldehyde against Escherichia coli and Salmonella enterica were studied by Manu (2016). For obtaining antiseptic and fungicidal effect, $E_{218}$, a methylparaben preservative, is used (Shapiro et al., 2002; Posey et al., 2005; Kromidas et al., 2006; Rebbeck et al., 2006; Ishiwatari et al., 2007; Meyer et al., 2007; Gopalakrishnan et al., 2012). It is also used in the composition of insecticides (Bell, 1990). According to the results of our studies, this substance also affects other parasitic nematodes of Ruminantia.

The impact of ethylenediaminetetraacetic acid (EDTA or trilon B) on Cryptococcus has been studied by Lai et al. (2016). Currently, fungal diseases are difficult to treat, and such treatment is conducted using expensive preparations. Therefore, these authors' work was aimed at intensifying the effect of modern preparations by using them with ethylenediaminetetraacetic acid and other synergic agents for decreasing the therapeutic dose, increasing the efficiency and preventing development of Cryptococcus resistance. The results of our experiments indicated that usage of trilon B did not cause any death of parasitic nematodes. Our study also indicates a 
high level of anthelminthic impact of methylparaben and raspberry ketone. These substances affect not only microorganisms and are used as a fungicide, but are also, according to the results of our tests, capable of having an effect on S. papillosus and H. contortus, parasitic nematodes of Ruminantia.

\section{Conclusions}

Additives used in the food industry are significant in the struggle against helminthiases of Ruminantia. Among the flavourings and source materials approved for use in and on foods, raspberry ketone and methylparaben are most efficient against nematode larvae. Minimum efficient dosage of solutions of these substances is $10 \mathrm{~g} / \mathrm{l}$ or $1 \%$ solution.

\section{References}

Belletti, N., Kamdem, S. S., Tabanelli, G., Lanciotti, R., \& Gardini, F. (2010). Modeling of combined effects of citral, linalool and $\beta$-pinene used against Saccharomyces cerevisiae in citrus-based beverages subjected to a mild heat treatment. International Joumal of Food Microbiology, 136(3), 283-289.

Belkind, B. A., Shammo, B., Dickenson, R., Rehberger, L. A., \& Heiman, D. F. (2013). Cinnamaldehyde and diallyl disulfide formulations and methods of use. U.S. Patent No. 20130018107. Libertyville, IL, USA.

Biffa, D., Jobre, Y., \& Chakka, H. (2006). Ovine helminthosis, a major health constraint to productivity of sheep in Ethiopia. Animal Health Research Reviews, 7(1-2), 107-118.

Bhutto, B., Phullan, M. S., Rind, R., \& Soomro, A. H. (2002). Prevalence of gastro-intestinal helminths in Buffalo Calves. Journal of Biological Sciences, 2(1), 43-45.

Boyko, O. O., Zazharska, N. M., \& Brygadyrenko, V. V. (2016). The influence of the extent of infestation by helminths upon changes in body weight of sheep in Ukraine. Visnyk of Dnipropetrovsk University. Biology, Ecology, 24(1), 3-7.

Boyko, A. A., \& Brygadyrenko, V. V. (2017). Changes in the viability of Strongyloides ransomi larvae (Nematoda, Rhabditida) under the influence of synthetic flavourings. Regulatory Mechanisms in Biosystems, 8(1), 36-40.

Boyko, A. A., \& Brygadyrenko, V. V. (2017). Changes in the viability of the eggs of Ascaris suum under the influence of flavourings and source materials approved for use in and on foods. Biosystems Diversity, 25(2), 162-166.

Burke, J. M., Wells, A., Casey, P., \& Kaplan, R. M. (2009). Herbal dewormer fails to control gastrointestinal nematodes in goats. Veterinary Parasitology, 160(1-2), 168-170.

Chalquest, R. R. (2002). Materials and methods for killing nematodes and nematode eggs. U.S. Patent No. 0016330. La Jolla, CA, USA.

Cheng, S.-S., Liu, J.-Y., Huang, C.-G., Hsui, Y.-R., Chen, W.-J., \& Chang, S.-T. (2009). Insecticidal activities of leaf essential oils from Cinnamomum osmophloeum against three mosquito species. Bioresource Technology, 100(1), $457-464$.

Chhetri, B., Ali, N., \& Setzer, W. (2015). A survey of chemical compositions and biological activities of Yemeni aromatic medicinal plants. Medicines, 2(2), 67-92.

Chiang, L.-C., Ng, L.-T., Cheng, P.-W., Chiang, W., \& Lin, C.-C. (2005). Antiviral activities of extracts and selected pure constituents of Ocimum basilicum. Clinical and Experimental Pharmacology and Physiology, 32(10), 811-816.

Cringoli, G., Veneziano, V., Jackson, F., Vercruysse, J., Greer, A. W., Fedele, V., Mezzino, L., \& Rinaldi, L. (2008). Effects of strategic anthelmintic treatments on the milk production of dairy sheep naturally infected by gastrointestinal strongyles. Veterinary Parasitology, 156(3-4), 340-345.

Faye, D., Leak, S., Nouala, S., Fall, A., Losson, B., \& Geerts, S. (2003). Effects of gastrointestinal helminth infections and plane of nutrition on the health and productivity of $F_{1}$ (West African Dwarf $\times$ Sahelian) goat crosses in The Gambia. Small Ruminant Research, 50(1-2), 153-161.

Gonzalez-Coloma, A., Diaz, C. E., Julio, L. F., Burilo, J., \& Fe Andres, M. (Eds.). (2017). A case study of MAPs production, uses and commercialization Artemisia absinthium var. candia L: Extract characterization and valorization. Frontiers in Horticulture, 1, 163-196.

Gopalakrishnan, S., Chitra, T. A., Aruna, A., \& Chenthilnathan, A. (2012). Development of RP-HPLC method for the simultaneous estimation of ambroxol hydrochloride, cetirizine hydrochloride and antimicrobial preservatives in combined dosage form. Der Pharma Chemica, 4(3), 1003-1015.

Ishiwatari, S., Suzuki, T., Hitomi, T., Yoshino, T., Matsukuma, S., \& Tsuji, T. (2006). Effects of methyl paraben on skin keratinocytes. Journal of Applied Toxicology, 27(1), 1-9.

Fahlbusch, K.-G., Hammerschmidt, F.-J., Panten, J., Pickenhagen, W., Schatkowski, D., Bauer, K., Garbe, D., \& Surburg, H. (2002). Flavors and fragrances. Ullmann's encyclopedia of industrial chemistry. Wiley-VCH, Weinheim.

Kloosterman, A., Ploeger, H. W., Pieke, E. J., Lam, T. J. G. M., \& Verhoeff, J. (1996). The value of bulk milk ELISA Ostertagia antibody titres as indicators of milk production response to anthelmintic treatment in the dry period. Veterinary Parasitology, 64(3), 197-205.

Knoblauch, C., \& Fry, K. (2011). Non-toxic insecticide. U.S. Patent No. 7956092. Edmonton, Alberta, CA, USA.

Kromidas, L., Perrier, E., Flanagan, J., Rivero, R., \& Bonnet, I. (2006). Release of antimicrobial actives from microcapsules by the action of axillary bacteria. International Journal of Cosmetic Science, 28(2), 103-108.

Lai, Y.-W., Campbell, L. T., Wilkins, M. R., Pang, C. N. I., Chen, S., \& Carter, D. A. (2016). Synergy and antagonism between iron chelators and antifungal drugs in Cryptococcus. International Journal of Antimicrobial Agents, 48(4), 388-394.

Lee, E.-J., Kim, J.-R., Choi, D.-R., \& Ahn, Y.-J. (2008). Toxicity of cassia and cinnamon oil compounds and cinnamaldehyde-related compounds to Sitophilus oryzae (Coleoptera: Curculionidae). Journal of Economic Entomology, 101(6), 1960-1966.

Lee, H. S. (2004). p-Anisaldehyde: Acaricidal component of Pimpinella anisum seed oil against the house dust mites Dermatophagoides farinae and Dermatophagoides pteronyssinus. Planta Medica, 70(3), 279-281.

Lide, D. R. (1998). Handbook of chemistry and physics (87 ed.). CRC Press, Boca Raton, FL.

Lindqvist, Å., Ljungström, B.-L., Nilsson, O., \& Waller, P. (2001). The dynamics, prevalence and impact of nematode infections in organically raised sheep in Sweden. Acta Veterinaria Scandinavica, 42(3), 377-389.

Lu, C. D., Gangyi, X., \& Kawas, J. R. (2010). Organic goat production, processsing and marketing: Opportunities, challenges and outlook. Small Ruminant Research, 89(2-3), 102-109.

Manu, D. K. (2016). Antimicrobial activity of cinnamaldehyde or geraniol alone or combined with high pressure processing to destroy Escherichia coli O157: $\mathrm{H} 7$ and Salmonella enterica in juices. Iowa State University, Ames, Iowa.

Meyer, B. K., Ni, A., Hu, B., \& Shi, L. (2007). Antimicrobial preservative use in parenteral products: Past and present. Journal of Pharmaceutical Sciences, 96(12), 3155-3167.

Na, Y. E., Kim, S.-I., Bang, H.-S., Kim, B.-S., \& Ahn, Y.-J. (2011). Fumigant toxicity of cassia and cinnamon oils and cinnamaldehyde and structurally related compounds to Dermanyssus gallinae (Acari: Dermanyssidae). Veterinary Parasitology, 178(3-4), 324-329.

Nomenclature of Organic Chemistry: IUPAC Recommendations and Preferred Names 2013 (Blue Book). (2014). The Royal Society of Chemistry, Cambridge.

Pedersen, M., \& Woldum, H. (2011). Oil-in-water formulation of avermectins. U.S. Patent No. 0009350. Lemvig, DK, USA.

Ploeger, H. W., Kloosterman, A., Bargeman, G., Wuijckhuise, L., \& van den Brink, R. (1990). Milk yield increase after anthelmintic treatment of dairy cattle related some parameters estimating helminth infection. Veterinary Parasitology, 35(1-2), 103-116.

Posey, R., Culbertson, E. C., \& Westermeier, J. C. (2005). Clear barrier coating and coated film. U.S. Patent No. 6911255. Greer, SC, USA.

Rahmann, G., \& Seip, H. (2006). Alternative strategies to prevent and control endoparasite diseases in organic sheep and goat farming systems. Ressortforschung für den Ökologischen Landbau, 298, 49-90.

Rebbeck, C., Hammond, R., Wong, J., Nair, L., Raghavan, N., Hepler, D., Campbell, W., \& Lynn, R. (2006). Solid-phase extraction and HPLC analysis of methylparaben and propylparaben in a concentrated antibiotic suspension. Drug Development and Industrial Pharmacy, 32(9), 1095-1102.

Ribeiro, P. R., de Castro, R. D., \& Fernandez, L. G. (2016). Chemical constituents of the oilseed crop Ricinus communis and their pharmacological activities: A review. Industrial Crops and Products, 91, 358-376.

Shapiro, S., Giertsen, E., \& Guggenheim, B. (2002). An in vitro oral biofilm model for comparing the efficacy of antimicrobial mouthrinses. Caries Research, 36(2), 93-100.

Soni, M. G., Taylor, S. L., Greenberg, N. A., \& Burdock, G. A. (2002). Evaluation of the health aspects of methyl paraben: A review of the published literature. Food and Chemical Toxicology, 40(10), 1335-1373.

Sato, K., Krist, S., \& Buchbauer, G. (2006). Antimicrobial effect of trans-cinnamaldehyde, (-)-perillaldehyde, (-)-citronellal, citral, eugenol and carvacrol on airborne microbes using an airwasher. Biological and Pharmaceutical Bulletin, 29(11), 2292-2294.

Shen, F., Xing, M., Liu, L., Tang, X., Wang, W., Wang, X., Wu, X., Wang, X., Wang, X., Wang, G., Zhang, J., Li, L., Zhang, J., \& Yu, L. (2012). Efficacy of trans-cinnamaldehyde against Psoroptes cuniculi in vitro. Parasitology Research, 110(4), 1321-1326.

Si, W., Ni, X., Gong, J., Yu, H., Tsao, R., Han, Y., \& Chambers, J. R. (2009). Antimicrobial activity of essential oils and structurally related synthetic food 
additives towards Clostridium perfringens. Journal of Applied Microbiology, 106(1), 213-220.

Somolinos, M., Garcia, D., Pagan, R., \& Mackey, B. (2008). Relationship between sublethal injury and microbial inactivation by the combination of high hydrostatic pressure and citral or tert-butyl hydroquinone. Applied and Environmental Microbiology, 74(24), 7570-7577.

Taylor, W. S. (2009). Flea control method. U.S. Patent No. 0036407. Wilmington, DE, USA.

Ullah, I., Khan, A. L., Ali, L., Khan, A. R., Waqas, M., Hussain, J., Lee, I. J., \& Shin, J.-H. (2015). Benzaldehyde as an insecticidal, antimicrobial, and antioxidant compound produced by Photorhabdus temperata M1021. Journal of Microbiology, 53(2), 127-133.

Veneziano, V., Rubino, R., Fedele, V., Rinaldi, L., Santaniello, M., Schioppi, M., Cascone, C., Pizzillo, M., \& Cringoli, G. (2004). The effects of five anthel- mintic treatment regimes on milk production in goats naturally infected by gastrointestinal nematodes. South African Journal of Animal Science, 34, 238-240.

Vercruysse, J., \& Claerebout, E. (2001). Treatment vs non-treatment of helminth infections in cattle: Defining the threshold. Veterinary Parasitology, 98(1-3), 195-214.

Van der Voort, M., Charlier, J., Lauwers, L., Vercruysse, J., Van Huylenbroeck, G., \& Van Meensel, J. (2013). Conceptual framework for analysing farmspecific economic effects of helminth infections in ruminants and control strategies. Preventive Veterinary Medicine, 109(3-4), 228-235.

Zajac, A. M., \& Conboy, G. A. (Eds.). (2011). Veterinary clinical parasitology. 8th ed. John Wiley and Sons, London. 